\title{
THE EFFECT OF CHIA AND SESAME FLOUR SUBSTITUTION TO NUTRIENT CONTENT AND SENSORY QUALITY OF MINI CROISSANT
}

\author{
Mira Sofyaningsih, Imas Arumsari \\ Nutrition Program, Faculty of Health Sciences, Prof. DR. HAMKA University of \\ Muhammadiyah, Jakarta 12130, Indonesia \\ ${ }^{*}$ Corresponding author, email: mirasn@uhamka.ac.id
}

\begin{abstract}
The use of flour made from sesame seed and chia seed could be applied into bakery products, such as croissant which made into "mini" form fits for one bite-size. Sesame flour contains considerable amount of calcium, fiber, and essential fatty acids compared to wheat flour. Chia flour also can be used as a substitution along with sesame flour as it is one source of linoleic acid. This study aims to develop a substituted mini croissant with added nutrient value and sensory acceptable. This is an experimental study with three levels of flour substitution $(0 \%, 10 \%$, and $20 \%)$, each experiment was performed duplicate with sesame flour and chia flour ratio was set at 1:2. The results showed that sesame and chia flour substitution significantly increased the fiber and calcium content of mini croissant, but not the carbohydrate content. Substitution significantly affected sensory profile, both for hedonic test and sensory quality.
\end{abstract}

Keywords: Calcium, Chia Flour, Dietary Fiber, Mini Croissant, Sesame Flour

\section{INTRODUCTION}

Metabolic syndrome is a symptom indicated by metabolic process disorders that leads to Non-Communicable Diseases (NCD), such as Diabetes Mellitus and hyperlipidemia. People with Diabetes mellitus cannot control the blood sugar level to normal, which causes hyperglycemia in the long period (Kilpatrick, Rigby, and Atkin, 2007). World Health Organization (WHO) reported that the incidence of Diabetes has increased from 4.7\% (1980) to $8.5 \%$ (2014) (WHO, 2016).

Carbohydrate is a substance that contributes to the rise of blood sugar level. The high carbohydrate intake increases the sugar level of postprandial, hyperinsulinemia, and insulin resistance (McKeown et al., 2004). Thus, the use of healthier food ingredients contributing to the decrease of metabolic syndrome has been a concern of global research nowadays, such as the food ingredients containing high fiber, calcium, and essential fatty acid. The high fiber food ingredients are choices to decrease postprandial sugar levels. Simultaneously, the calcium is useful for maintaining intracellular calcium concentration that affects insulin release activities. The essential fatty acids have the advantage of maintaining HDL and LDL stability in the blood. The use of fiber, calcium, and fatty acid in chia seed and sesame seed in the food product are useful for increasing the nutrient value.

Chia seed (Salvia hispanica) is the most-consumed seed in South America. The study showed that chia seed contains polysaccharides, essential fatty acids, and protein (Lin, Daniel, and Whistler, 1994; Ixtaina et al., 2011), food fiber, and protein (Kulczyński et al., 2019). The choice of chia seed is due to its linolenic fatty acids (omega3), and also its proportion of linoleic fatty acids and linolenic fatty acids (the best omega-6/omega-3 ratio, that is 0.3 (Dubois et al., 2007). The balanced ratio of omega-6/omega 3 , about $1-2 / 1$, is essential in preventing obesity, other than physical activities. The lower omega 6/omega 3 ratio becomes a matter to consider in obesity management (Simopoulos, 2016). 
Furthermore, a study conducted by $\mathrm{Ho}$ et al. (2013) revealed that both ground and whole Salba (a chia seed variety) addition in bread have the same effectivity in decreasing blood glucose levels. Chia seed has a plentiful advantage; however, the research has not been conducted yet on this ingredient in Indonesia.

There is also another potential ingredient to be developed beside chia, namely sesame. Sesame (Sesamum indicum) is a seed variety that contains essential fatty acids and antioxidants (Xu, Chen, and Hu, 2005). Moreover, it has a high-fat content of $55 \%$ and protein of $20 \%$, and rich in linoleic fatty acids and oleic fatty acids (Martinchik, 2011). The research result by Prasad et al. (2012) showed sesame has relatively high calcium of 960 $\mathrm{mg} / 100 \mathrm{~g}$ and $5.5 \%$ fiber.

Furthermore, Lestari (2018), in her research on puff pastry making by sesame flour substitution, showed the protein content of $9.99 \%$, carbohydrate of $39.45 \%$, total fat of $41.10 \%$, oleic acids (omega-9) $15.32 \%$, linoleic acids (omega-6) of $5.74 \%$, and linoleic acids (omega-3) of $0.08 \%$. Also, it showed a significant enough omega- 6 dan omega-3 ratio, i.e., 71.75. Therefore, the research added chia seed by the best omega- 6 dan omega- 3 ratio and high fiber food content.

The chosen product to be developed is puff pastry class but made into mini croissant form. Croissant is one of the popular and consumer-most-intended-product due to its savory taste and a crunchy-flaky texture. The present popular concept of the product is 'one bitesize,' and 'share it' means to share with others. Hence, this research focused on croissants in mini size. This research aims to develop mini croissants with substitution of chia seed flour and sesame flour that have added value on the nutrient content, particularly fiber and calcium, while considering consumer's preference.

\section{METHODOLOGY}

\section{Materials}

The research used the following ingredients to make mini croissants: "Cakra" wheat flour, sesame flour, chia flour, korsvet, butter, lemon juice, salt, and water. That aside, the organoleptic test used mini croissants and bottled water. The chemical ingredients for proximate and calcium analysis are also used.

\section{Equipment}

This research used the following tools to make mini croissants; basin, mixer, scale, knife, spatula, rolling pin, brush, oven, plastic, and baking sheet. The instruments used for product chemical analysis are the analytical service laboratory method (Saraswanti Indo Genetech, Bogor).

\section{Research Design}

This research is an experimental research using a Completely Randomized Design with two replications. The treatment parameter in this study was the substitution level of wheat flour with chia flour and sesame flour.

The consecutive research stages are as follows.

- Stage 1 = F0: substitution $0 \%$,

- Stage 2 = F1: substitution 10\% (chia flour : sesame flour = 2:1),

- Stage 3 = F2: substitution 20\% (chia flour : sesame flour $=2: 1$ ).

To figure out the treatment effect on the organoleptic quality and nutritional quality, statistic test was performed. One-way KRUSKAL-WALLIS in the SPSS application version 22 by a confidence level of $95 \%$ was employed. If the treatment effect is significant, then the process proceeded with the Tukey Test. The data analysis of the organoleptic test is by analyzing the data trend in the spider chart.

\section{Research Stage}


This research was conducted through two stages. In the raw material preparation process (Stage 1), the chia seed and sesame seed is made into flour to substitute in the croissant making and formulation. In stage 2, the organoleptic test was performed by 5 hedonic scales to observe panelists' preference in terms of color, aroma, texture, and flavor using semi-trained panels (Nasir et al., 2010; Albert et al., 2011; Alexi et al., 2018). This research also involved 70 students as panelists who have passed the Nutrition Program's sensory analysis course at the Prof. DR. Hamka University of Muhammadiyah. The chemical analysis was carried out to know the effect of the chia flour and sesame flour substitution level on the nutritional content (proximate, calcium, and dietary fiber) of the mini croissants produced.

\section{Methods}

The chia flour and sesame flour making used a roasting method before the flouring process. The chia flour making adopted the Haripriya and Aparna (2018) method with a few modifications on the roasting time and sieving process. The croissant making was carried out through several stages: the ingredients mixing, which follows formula provided in Table 1, dough folding to obtain a flaky structure as the product characteristics, and baking.

Table 1. Mini Croissant's Ingredients for The Three Formulas

\begin{tabular}{lccc}
\hline \multicolumn{1}{c}{ Ingredients } & $\begin{array}{c}\text { F0 (Without } \\
\text { Substitution) }\end{array}$ & $\begin{array}{c}\text { F1 (Substitution } \\
\mathbf{1 0 \%}\end{array}$ & $\begin{array}{c}\text { F2 (Substitution } \\
\mathbf{2 0 \%})\end{array}$ \\
\hline Wheat flour $(\mathrm{g})$ & 200 & 180 & 160 \\
Sesame flour $(\mathrm{g})$ & - & 6.7 & 13.3 \\
Chia flour $(\mathrm{g})$ & - & 13.3 & 26.7 \\
Salt $(\mathrm{g})$ & 2 & 2 & 2 \\
Water (ml) & 70 & 70 & 70 \\
Lemon juice (ml) & 5 & 5 & 5 \\
Korsvet (g) & 85 & 85 & 85 \\
Butter (g) & 40 & 40 & 40 \\
\hline
\end{tabular}

\section{Analytical Procedures}

The analysis performed was in the form of an organoleptic test consisting of a preference test (hedonic) and a hedonic quality test involving 70 semi-trained panelists (Handayani et al., 2014). The preference test (hedonic) assessed several aspects, i.e. color, aroma, texture, and flavor, and were measured by 5 hedonic scales, namely 1: very dislike; 2: dislike; 3: rather like; 4: like; 5 : very like.

The hedonic quality test assessed aroma, texture, and flavor level. In terms of aroma, it involved 5 scales; they are 1: very unreal nutty aroma; 2 : unreal nutty aroma; 3 : rather real nutty aroma; 4: real nutty aroma, and 5: very real nutty aroma. Hedonic quality test also covered 5 scales, namely 1: very not crunchy; 2: not crunchy; 3 : rather crunchy; 4: crunchy; 5: very crunchy. The flavor's hedonic quality test consisted of 5 scales, i.e., 1: very tasteless; 2: tasteless; 3: rather tasteful, 4: tasteful; 5: very tasteful.

The chemical analysis was carried out in the Saraswati Indo Genetech Laboratory, Bogor. The calcium levels analysis was performed using the ICP-OES spectrometer method (18-13-1/MU/SMM-SIG, ICP-OES = Inductively Coupled Plasma-Optical Emission Spectrometry (ICP-OES); fiber analysis (18-8-6-2/MU/SMM-SIG). The proximate analysis includes water content by oven method (SNI 01-2891-1992 point 5.1), the ash content by dry ashing method (SNI 01-28911992 point 6.1), protein content by Kjeldahl method (18-8$31 / \mathrm{MU} / \mathrm{SMM}-\mathrm{SIG}$, Kjeltec), the fat content by the Soxhlet method (18-8-5/MU/SMM-SIG, Weibull), and carbohydrate content (18-8-9/MU/SMM-SIG).

RESULT AND DISCUSSION 
1. The Proximate, Calcium, Fiber Analysis Result and Their Ratio/Comparison with Wheat Flour.

The analysis results in question are provided in Table 2 below.

Table 2. The Proximate, Calcium, and Sesame Flour Fiber, Chia Flour versus Wheat Flour

\begin{tabular}{|c|c|c|c|}
\hline Energy and nutrients & Sesame Flour* & Chia Flour* & Wheat Flour** \\
\hline Total energy (kkal/100 g) & 670.86 & 519.59 & 333 \\
\hline $\begin{array}{l}\text { Energy and Fat (kkal/100 } \\
\text { g) }\end{array}$ & 530.1 & 293.27 & 9.0 \\
\hline Water (\%) & 2.88 & 6.08 & 11.8 \\
\hline Ash (\%) & 3.04 & 4.76 & 1.0 \\
\hline Protein (\%) & 24.88 & 26.23 & 9.0 \\
\hline Fat $(\%)$ & 58.9 & 32.59 & 1.0 \\
\hline Carbohydrate (\%) & 10.31 & 30.35 & 77.2 \\
\hline Calcium (mg/100 g) & 151.97 & 617.05 & 22 \\
\hline Dietary fiber (\%) & 10.08 & 30.24 & 0.3 \\
\hline
\end{tabular}

The proximate, calcium, and fiber analysis results on the wheat flour substitute ingredients, sesame flour, and chia flour, showed a significant difference compared to the wheat flour as the raw material. The advantages of sesame flour and chia flour over wheat flour are calcium, fiber, fat, protein, and ash contents. According to the result, it was then carried out a substitution of wheat flour with both ingredients; thus, it was expected that there would be a significant increase in the calcium, fiber, fat, and protein level.

According to Table 2, the chia flour dietary fiber content is far above wheat flour and sesame flour. The analysis result of dietary fiber for chia flour was $30.24 \%$. This result has no significant difference from the dietary fiber level of chia seeds, which is $30.2 \%$ (Jin et al., 2012) and based on the USDA (2016) in Kulczyński et al., (2019) of 34.4\%. The slight difference between the flour and chia seeds' dietary fiber content is that chia flour is made through a delicate physical process, namely roasting for approximately 6 minutes and grinding by a blender did not significantly decrease dietary fiber. Furthermore, in line with the research by Valiente et al. (1994) roasting process does not affect the total dietary fiber of cacao beans, insoluble dietary fiber will be redistributed following roasting dissolved food does not show a considerable variation. Besides, the research conducted by Haripriya and Aparna (2018) showed that the increase of total dietary content was $17.61 \%$ of the chia flour as the dry roasting result.

2. Hedonic Test Result (Preference) of Mini Croissant of The Three Formulas (F0, F1, F2)

The hedonic test result and the significant differences analysis between treatment levels by Kruskal Wallis test and a further testing by Mann-Whitney test are presented in Table 3 as follows.

Table 3. The Sesame Flour and Chia Flour Effect on The Color, Aroma, Texture, and Flavor Hedonic Score

\begin{tabular}{|c|c|c|c|c|c|}
\hline \multicolumn{2}{|c|}{ Treatment } & Color & Aroma & Texture & Flavor \\
\hline $\begin{array}{l}\text { F0 (control, } \\
\text { substitution) }\end{array}$ & without & $3.96 \pm 0.09^{a}$ & $4.10 \pm 0.10^{a}$ & $3.86 \pm 0.09^{a}$ & $3.73 \pm 0.10^{\mathrm{a}}$ \\
\hline $\begin{array}{l}\mathrm{F} 1 \quad(10 \% \\
\text { substitution) }\end{array}$ & $(w / w)$ & $3.53 \pm 0.11^{b}$ & $3.70 \pm 0.92^{b}$ & $3.69 \pm 0.11^{a}$ & $3.43 \pm 0.10^{a}$ \\
\hline $\begin{array}{l}\mathrm{F} 2 \quad(20 \% \\
\text { substitution) }\end{array}$ & $(w / w)$ & $2.79 \pm 0.07^{c}$ & $3.33 \pm 0.12^{\mathrm{c}}$ & $2.91 \pm 0.11^{b}$ & $2.93 \pm 0.12^{b}$ \\
\hline
\end{tabular}


a, b, c The difference in letter denotes a significant different between treatment levels $(p<0.05)$ in the non-parametric tests, Kruskal Wallis, followed by Mann-Whitney test

The highest panelists' average score on the croissant color preference was in the F0 formula (control). The higher the substitution level, the smaller the color hedonic score. The panelists preferred F0 for the croissant has a brighter color than the substituted croissant, which tends to be darker. It is because the chia flour's color is darker than the wheat flour. The chia flour appearance is shown in Figure 1, while the products' color is in Figure 2.

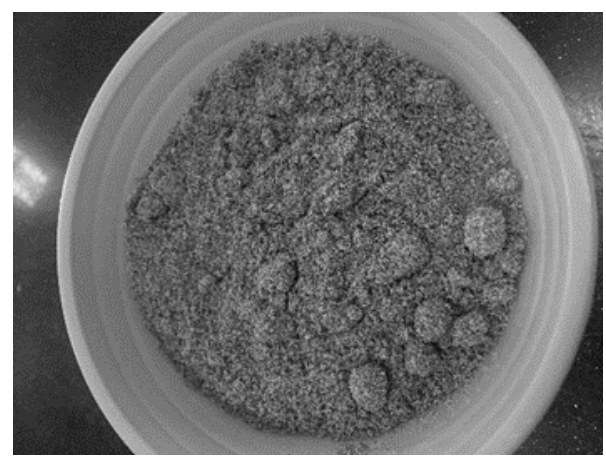

Figure 1. Chia Flour

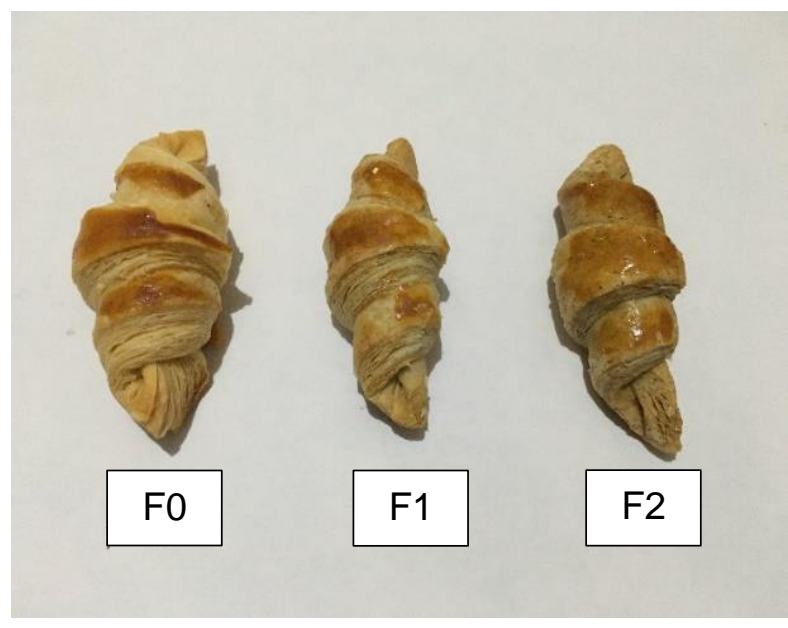

Figure 2. Mini Croissants' Appearance of The Three Formulas

The panelists preferred the brighter color in line with Surayya et al. (2020) that showed the sorghum bar color with sorghum Nira sap coating $20 \%$ was not preferred by sorghum sap coating $10 \%$ because it has a darker color. The difference test result showed that chia flour and sesame flour's substitution level significantly affected panelists' preference regarding color parameters. Based on the further testing result, the panelists' preference on the color was varied.

The highest panelists' average score on the croissant's aroma was in the F0 formula (control). The higher the substitution level, the smaller the aroma hedonic score/hedonic score on the aroma. The panelists preferred F0 because it smells more buttery than those other substituted formulas that tend to have a nutty aroma. The chia flour and sesame flour significantly affected panelists' preference in terms of aroma parameters. Furthermore, the Kruskal-Wallis test showed that chia flour and sesame flour's substitution level significantly affected panelists' preference in terms of aroma parameters. The Mann-Whitney further testing indicated the panelists' preferences on the color were vary.

The highest panelists' average score on the croissant texture preference was also in the F0 formula (control). The higher the substitution level, the smaller the hedonic score on the texture. The panelists preferred F0 because the croissant's texture was more crispy and 
flaky than the substituted croissants' texture. The Kruskal-Wallis test result showed that chia flour and sesame flour's substitution level significantly affected panelists' preference in terms of texture parameters. Moreover, the Mann-Whitney further testing showed the panelists' preferences on the F0 and F1 formula's texture are the same. Such hedonic test results are expected because statistically, the texture is similar to the FO formula, meaning that up to $10 \%$ of substitution rate is still acceptable. The product with puff pastry dough, which has a flaky texture, enacted the texture parameters to determine product quality.

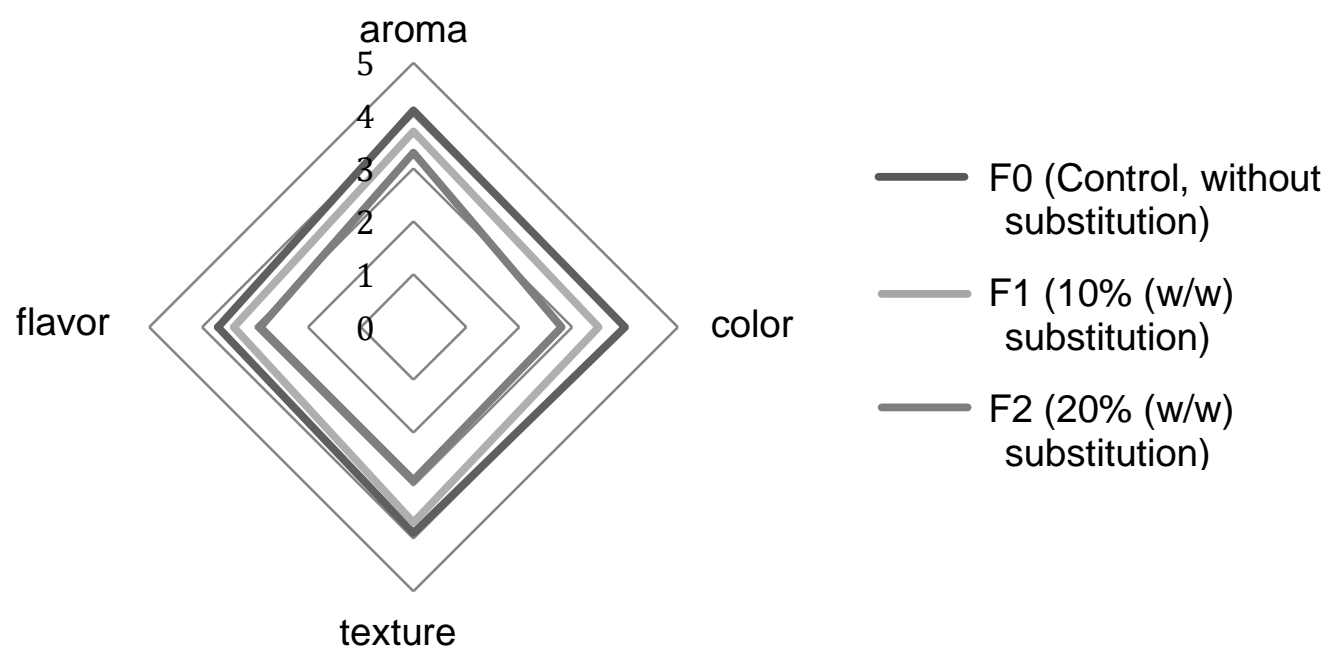

Figure 3. The Hedonic Profile Spider Chart of Control, and Substitution Formulas

The highest panelists' average score on the croissant flavor preference was also in the F0 formula (control). The higher the substitution level, the smaller the flavor hedonic score. It also indicated that the panelists preferred the products without substitution for their buttery flavor as the product's characteristics were still dominant. The buttery taste of the substituted products was reduced due to the sesame and chia's nutty taste. The Mann-Whitney further testing result showed that chia flour and sesame flour's substitution level significantly affected panelists' preference on the flavor parameters. That aside, the Mann-Whitney further testing showed the panelists' preferences on the F0 and F1 formulas' flavor is the same. Such hedonic test results are expected because statistically, the flavor is similar to the F0 formula, meaning that up to $10 \%$ of substitution rate is still acceptable. The flavor parameters come into a major consideration in which product customers make their choice. According to the hedonic profile spider chart, it is clearly showed that F1 croissant is closer to control products in terms of the texture and flavor (Figure 3). On the other hand, the hedonic profile of the F2 formula makes the gap further from the control than F1. It means that a substitution rate of up to $10 \%$ is still acceptable.

3. The Hedonic Quality Test Result of The Mini Croissant of The Three Formulas (F0, F1, $\mathrm{F} 2$ )

The hedonic quality test result and the significant differences analysis between the treatment levels by Kruskal-Wallis and the Mann-Whitney test further testing are described in the following table.

Table 4. The Sesame Flour, and Chia Flour Substitution Effect on The Hedonic Quality Score on The Aroma, Texture, and Flavor

\begin{tabular}{lccc}
\multicolumn{1}{c}{ Treatment } & Aroma & Texture & Flavor \\
\hline F0 (control, without substitution) & $2.76 \pm 0.13^{\mathrm{a}}$ & $4.01 \pm 0.08^{\mathrm{a}}$ & $3.99 \pm 0.09^{\mathrm{a}}$ \\
F1 (10\% (w/w) substitution) & $2.80 \pm 0.12^{\mathrm{a}}$ & $3.61 \pm 0.11^{\mathrm{b}}$ & $3.59 \pm 0.10^{\mathrm{b}}$ \\
F2 $(20 \%(\mathrm{w} / \mathrm{w})$ substitution) & $2.61 \pm 0.12^{\mathrm{a}}$ & $2.74 \pm 0.13^{\mathrm{c}}$ & $2.89 \pm 0.13^{\mathrm{c}}$ \\
\hline
\end{tabular}


$a, b, c$ The difference in letter denotes a significant different between treatment levels

$(p<0.05)$ in the non-parametric tests, Kruskal Wallis, followed by Mann-Whitney test

The panelists' assessment of the aroma quality hedonic showed that F1 has the highest score, followed by F0 and F2. However, if it is analyzed statistically by KruskalWallis, the substitution level had no significant effect.

The highest panelists' assessment score in terms of texture quality was F0, followed by F1 and F2. The substitution significantly affected panelists' assessment of the hedonic quality of the texture.

The sesame flour and chia flour substitution level also significantly affected flavor hedonic quality. The F0 formula obtained the highest score, followed by F1 and F2.

According to the hedonic quality profile spider chart (Figure 4), the highest average score is the hedonic quality of the texture, followed by the flavor hedonic quality, and the aroma hedonic quality. Thus, the more acceptable substitution level of sesame flour and chia flour is $10 \%$.

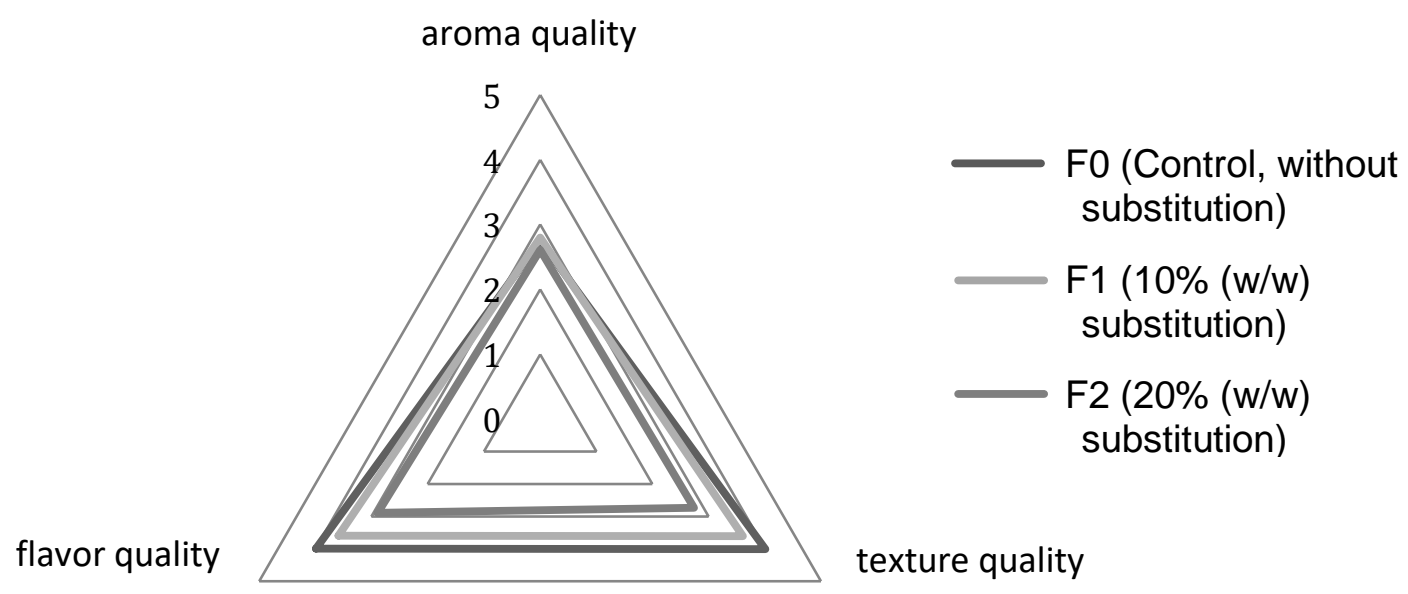

Figure 4. The Hedonic Quality Profile Spider Chart on The Control and The Substitution Formula

4. The Proximate, Calcium, and Fiber Analysis Result

The proximate, calcium, and fiber analysis result on the mini croissant and the analysis of the significant differences between treatment levels by Kruskal-Wallis and further testing by Mann-Whitney are presented in Table 5 and Table 6 as follow.

Table 5. Sesame Flour and Chia Flour Substitution Effect on The Proximate Level of The Croissants

\begin{tabular}{lccccc}
\hline Treatment & $\begin{array}{c}\text { Water } \\
\text { Content (\%) }\end{array}$ & $\begin{array}{c}\text { Ash } \\
\text { Content } \\
(\%)\end{array}$ & $\begin{array}{c}\text { Protein } \\
\text { Content (\%) }\end{array}$ & $\begin{array}{c}\text { Fat } \\
\text { Content } \\
(\%)\end{array}$ & $\begin{array}{c}\text { Carbohydrate } \\
\text { Content (\%) }\end{array}$ \\
\hline $\begin{array}{l}\text { F0 (control, } \\
\text { without }\end{array}$ & $7.15 \pm 0.08^{\mathrm{a}}$ & $1.10 \pm 0.06^{\mathrm{a}}$ & $8.78 \pm 0.20^{\mathrm{a}}$ & $37.04 \pm 0.15^{\mathrm{a}}$ & $45.76 \pm 0.15^{\mathrm{a}}$ \\
$\begin{array}{l}\text { substitution) } \\
\begin{array}{l}\text { F1 }(10 \%(w / w) \\
\text { substitution })\end{array}\end{array}$ & $11.29 \pm 0.06^{\mathrm{b}}$ & $1.72 \pm 0.02^{\mathrm{b}}$ & $9.14 \pm 0.06^{\mathrm{a}}$ & $36.82 \pm 0.33^{\mathrm{a}}$ & $41.24 \pm 0.47^{\mathrm{a}}$ \\
$\begin{array}{l}\text { F2 }(20 \%(\mathrm{w} / \mathrm{w}) \\
\text { substitution })\end{array}$ & $9.44 \pm 0.15^{\mathrm{c}}$ & $2.20 \pm 0.02^{\mathrm{c}}$ & $10.13 \pm 0.08^{\mathrm{b}}$ & $39.47 \pm 0.16^{\mathrm{b}}$ & $41.06 \pm 1.62^{\mathrm{a}}$ \\
\hline
\end{tabular}


Data are presented in mean \pm SEM $(n=2)$

$a, b, c$ The difference in letter denotes a significant difference between treatment levels $(p<0.05)$ in the non-parametric tests, Kruskal Wallis, followed by the Mann-Whitney test

Table 6. Sesame Flour and Chia Flour Substitution Effect on The Calcium and Fiber Level of The Croissants

\begin{tabular}{lcc}
\hline \multicolumn{1}{c}{ Treatment } & Calcium $(\mathbf{m g} / \mathbf{1 0 0 g})$ & Fiber $(\mathbf{g} / \mathbf{1 0 0 g})$ \\
\hline F0 (control, without substitution) & $179.34 \pm 6.42^{\mathrm{a}}$ & $13.02 \pm 0.06^{\mathrm{a}}$ \\
F1 $(10 \%(\mathrm{w} / \mathrm{w})$ substitution ) & $260.30 \pm 2.94^{\mathrm{b}}$ & $15.46 \pm 0.39^{\mathrm{b}}$ \\
F2 $(20 \%(\mathrm{w} / \mathrm{w})$ substitution $)$ & $277.05 \pm 4.71^{\mathrm{bc}}$ & $15.25 \pm 0.37^{\mathrm{b}}$ \\
\hline
\end{tabular}

Data presented in mean \pm SEM $(n=2)$

$a, b, c$ The difference in letter denotes a significant difference between treatment levels $(p<0.05)$ in the non-parametric tests, Kruskal Wallis, followed by the Mann-Whitney test

The sesame flour and the chia flour substitution level generally increased the nutritional value of the croissants. The Kruskal-Wallis statistical test showed that excepting on the carbohydrate level; the substitution level significantly affects the proximate, calcium, and fiber test.

Croissant's water content tends to be increased with the substitution treatment. It is because of the higher sesame flour and the chia flour substitution levels, the higher the fiber content, and the lower the gluten content. The presence of fiber makes it more difficult for water to evaporate during the roasting process because it is water-absorbent. Moreover, dough's lower gluten content caused the lower water molecule to be released during the roasting (Widjanarko, 2008 in Subandoro et al., 2013).

The ash content became higher with the increase of substitution level. It is previously known that the calcium content of sesame flour and chia flour are much higher than wheat flour. Besides, mini croissants' higher ash content with the highest substitution level $(20 \%)$ caused the product's color to become darker, had a bad texture and were not crunchy. In line with Wiryadi's (2007) statement in Subandoro et al. (2013) if the ash content is too high, it could produce a bad color and texture.

The calcium, fiber, and protein content also increased with the high level of substitution. The higher fat contained in a substituted croissant is not necessarily a negative point. These fats contain essential fatty acids that are useful for health; mainly, chia flour contains high linolenic acid (omega 3 acids), and omega acids which are low in plant-based foods. It then turns into the reason for chia seed selection as wheat flour substitutes.

However, the carbohydrate content showed reverse result, which is decreased by the increasing of substitution level. The higher wheat flour's carbohydrate content compared to the sesame flour and chia flour is the cause of this trend. According to Sugito and Ari Hayati (2006) in Subandoro et al. (2013), the carbohydrate content measured by difference was affected by other nutritional components; the lower the other nutritional components, the higher the carbohydrate content. Nutritional components that affect the amount of carbohydrate content include protein, fat, water, and ash content. Sesame flour and chia flour have higher levels of ash, protein, fat, calcium, and fiber than those in wheat flour (Table 2).

\section{CONCLUSION}

The sesame flour and chia flour substitution significantly affected the preference levels and hedonic quality of croissants, except for the aroma hedonic quality. Mini croissants with a $10 \%$ substitution level can match mini croissants' preferred level without substitution on the texture and taste parameters.

Additionally, the sesame flour and chia flour substitution significantly increased the calcium and croissant's fiber content and decreased its carbohydrate content. Moreover, the sesame flour and chia flour substitution significantly affected the mini croissants' proximate profile. The higher the substitution level, the croissants' nutritional value will also increase 
(except the carbohydrate content) because the sesame flour and chia flour are superior in nutritional value compared to wheat flour.

Thus, to increase the croissants' nutritional value with puff pastry dough can be carried out using the substitution of raw material which has $10 \%$ higher nutritional value than wheat flour or with the following ratio, sesame flour : chia flour $=1: 2$ because it has a hedonic profile and hedonic quality that is close to the control products (without substitution). Further research is required to analyze the essential fatty acids (omega 3, 6, and 9) profile.

\section{ACKNOWLEDGEMENT}

The author's gratitude goes to the Research Institute of Prof. DR. HAMKA University of Muhammadiyah that fully funded this research. The research assistant also participated in this study are Widya Lestari and the Laboratory Assistant for Nutrition Study Program of Prof. DR. Hamka University of Muhammadiyah.

\section{REFERENCE}

Albert, A., Varela, P., Salvador, A., Hough, G., \& Fiszman, S. (2011). Overcoming the issues in the sensory description of hot served food with a complex texture. Application of QDA®, flash profiling and projective mapping using panels with different degrees of training. Food Quality and Preference, 22(5), 463-473. https://doi.org/10.1016/j.foodqual.2011.02.010

Alexi, N., Nanou, E., Lazo, O., Guerrero, L., Grigorakis, K., \& Byrne, D. V. (2018). Check-AllThat-Apply (CATA) with semi-trained assessors: Sensory profiles closer to descriptive analysis or consumer elicited data? Food Quality and Preference, 64, 11-20. https://doi.org/10.1016/j.foodqual.2017.10.009

Arumsari, I., \& Sofyaningsih, M. (2020). Evaluation of Nutrient Content of Chia Flour (Salvia hispanica L.) and Sesame Flour (Sesamum indicum L.) as Alternative Flour Rich in Fiber and Protein. ARGIPA (Arsip Gizi Dan Pangan), 5(1), 27-33. https://doi.org/10.22236/argipa.v5i1.4950

Dubois, V., Breton, S., Linder, M., Fanni, J., \& Parmentier, M. (2007). Fatty Acid Profiles of 80 Vegetable Oils with Regard to Their Nutritional Potential. European Journal of Lipid Science and Technology, 109(7), 710-732. https://doi.org/10.1002/ejlt.200700040

Handayani, R., \& Aminah, S. (2014). Variasi substitusi rumput laut terhadap kadar serat dan mutu organoleptik cake rumput laut (Eucheuma cottonii). Jurnal Pangan dan Gizi, 2(1): 67-74

Haripriya, A., \& Aparna, N. (2018). Effect of Roasting on Selected Nutrient Profile and Functional Properties of Chia Seeds (Salvia hispanica) and Optimization of Chia Seed Based Instant Soup Mix. International Journal of Food Science and Nutrition, 3(2), 200-206.

Ho, H., Lee, A. S., Jovanovski, E., Jenkins, A. L., DeSouza, R., \& Vuksan, V. (2013). Effect of Whole and Ground Salba Seeds (Salvia Hispanica L.) on Postprandial Glycemia in Healthy Volunteers: A Randomized Controlled, Dose-response Trial. European Journal of Clinical Nutrition, 67(7), 786-788. https://doi.org/10.1038/ejcn.2013.103

Ixtaina, V. Y., Martínez, M. L., Spotorno, V., Mateo, C. M., Maestri, D. M., Diehl, B. W. K., ... Tomás, M. C. (2011). Characterization of Chia Seed Oils Obtained by Pressing and Solvent Extraction. Journal of Food Composition and Analysis, 24(2), 166-174. https://doi.org/10.1016/j.jfca.2010.08.006

Jin, F., Nieman, D. C., Sha, W., Xie, G., Qiu, Y., \& Jia, W. (2012). Supplementation of Milled Chia Seeds Increases Plasma ALA and EPA in Postmenopausal Women. Plant Foods for Human Nutrition, 67(2), 105-110. https://doi.org/10.1007/s11130-012-0286-0

Kementerian Kesehatan RI (Ministry of Health of the Republic of Indonesia). (2019). Tabel Komposisi Pangan Indonesia. Retrieved June 17, 2020, from https://www.andrafarm.com/_andra.php?_i=daftar-tkpi

Kilpatrick, E. S., Rigby, A. S., \& Atkin, S. L. (2007). Insulin Resistance, the Metabolic 
Syndrome, and Complication Risk in Type 1 Diabetes: "Double diabetes" in the Diabetes Control and Complications Trial. Diabetes Care, 30(3), 707-712. https://doi.org/10.2337/dc06-1982

Kulczyński, B., Kobus-Cisowska, J., Taczanowski, M., Kmiecik, D., \& Gramza-Michałowska, A. (2019). The Chemical Composition and Nutritional Value of Chia Seeds-Current State of Knowledge. Nutrients, 11(6), 1242. https://doi.org/10.3390/nu11061242

Lestari, W. (2018). Penambahan Tepung Wijen Putih (Sesamum indicum) pada Pembuatan Puff Pastry untuk Meningkatkan Asam Lemak Esensial. UHAMKA.

Lin, K.-Y., Daniel, J. R., \& Whistler, R. L. (1994). Structure of Chia Seed Polysaccharide Exudate. Carbohydrate Polymers, 23(1), 13-18. https://doi.org/10.1016/01448617(94)90085-X

Martinchik, A. N. (2011). Nutritional Value of Sesame Seeds. Vopr Pitan, 80(3), 41-43.

McKeown, N. M., Meigs, J. B., Liu, S., Saltzman, E., Wilson, P. W. F., \& Jacques, P. F. (2004). Carbohydrate Nutrition, Insulin Resistance, and the Prevalence of the Metabolic Syndrome in the Framingham Offspring Cohort. Diabetes Care, 27(2), 538546. https://doi.org/10.2337/diacare.27.2.538

Nasir, M., Siddiq, M., Ravi, R., Harte, J. B., Dolan, K. D., \& Butt, M. S. (2010). Physical Quality Characteristics and Sensory Evaluation of Cookies Made with Added Defatted Maize Germ Flour. Journal of Food Quality, 33(1), 72-84. https://doi.org/10.1111/j.1745-4557.2009.00291.x

Prasad MN, N., KR, S., \& S. Prasad, D. (2012). A Review on Nutritional and Nutraceutical Properties of Sesame. Journal of Nutrition \& Food Sciences, 02(02), 1-6. https://doi.org/10.4172/2155-9600.1000127

Simopoulos, A. (2016). An Increase in the Omega-6/Omega-3 Fatty Acid Ratio Increases the Risk for Obesity. Nutrients, 8(3), 128. https://doi.org/10.3390/nu8030128

Subandoro, R. H., Basito, \& Atmaka, W. (2013). Pemanfaatan Tepung Millet Kuning dan Tepung Ubi Jalar Kuning Sebagai Subtitusi Tepung Terigu dalam Pembuatan Cookies Terhadap Karakteristik Organoleptik dan Fisikokimia. Jurnal Teknosains Pangan, 2(4), 68-74.

Surayya, N. A., Hilaili, M., Rahmawati, E., Primadiani, E., Syauqi, J. A., Rushydi, A. N., \& Wulan, S. N. (2020). Sifat Organoleptik dan Indeks Glikemik Produk Sorgum Bar yang Diformulasi Menggunakan Berbagai Jenis Penyalut Nira. Jurnal Pangan Dan Agroindustri, 8(2), 56-67. https://doi.org/10.21776/ub.jpa.2020.008.02.1

USDA. (2016). The Plants Database: Artocarpus heterophyllus Lam. Jackfruit. Greensboro.

Valiente, C., Esteban, R. M., Molla, E., \& Lopez-Andreu, F. J. (1994). Roasting Effects on Dietary Fiber Composition of Cocoa Beans. Journal of Food Science, 59(1), 123-124. https://doi.org/10.1111/j.1365-2621.1994.tb06914.x

WHO. (2016). Diabetes. Retrieved March 30, 2020, from https://www.who.int/newsroom/fact-sheets/detail/diabetes

Xu, J., Chen, S., \& Hu, Q. (2005). Antioxidant Activity of Brown Pigment and Extracts from Black Sesame Seed (Sesamum indicum L.). Food Chemistry, 91(1), 79-83. https://doi.org/10.1016/j.foodchem.2004.05.051 